\title{
On the amine-catalyzed Suzuki-Miyaura coupling using a catalysis-based fluorometric method
}

\author{
Jincy K. Vinod, Annelise K. Wanner, Elizabeth I. James, and Kazunori Koide* \\ Department of Chemistry, University of Pittsburgh \\ 219 Parkman Avenue, Pittsburgh, Pennsylvania 15260, United States \\ koide@pitt.edu
}

\begin{abstract}
The Suzuki-Miyaura coupling is one of the most frequently used reactions in organic synthesis. Recent work by others suggested that an arylamine, prepared by palladium catalysis and tricyclohexylphosphine, could catalyze Suzuki-Miyaura coupling reactions without transition metals. Herein, we used a fluorometric quantification method for palladium previously developed in our laboratory to unambiguously conclude that there is a correlation between the palladium content in the arylamine and the rate of a Suzuki-Miyaura coupling. Also, our mass spectroscopic analysis of the arylamine revealed the presence of a palladium-phosphine complex. When $\mathrm{Pd}(\mathrm{OAc})_{2}$ was used as a catalyst for the same Suzuki-Miyaura coupling, tricyclohexylphosphine was detrimental to the coupling and that the arylamine played negligible role. This study demonstrates the utility of the fluorometric technology for catalysis research.
\end{abstract}

The palladium-catalyzed Suzuki-Miyaura coupling is one of the most frequently used reactions in organic synthesis. ${ }^{1}$ However, due to the perceived toxicity and cost, there have been attempts to develop palladium-free Suzuki-Miyaura and related methods..$^{2-6}$ In several cases, trace palladium was present in the reagents and catalyzed the reactions. ${ }^{4,7-12}$ In 2021, the Xu group reported an amine-catalyzed Suzuki-Miyaura-type coupling of aryl halides and arylboronic acids. ${ }^{13}$ They prepared arylamine $\mathbf{1}$ by a palladium-catalyzed reaction between 1bromo-2-methylbenzene and 2-methylbenzene 1,3-diamine in the presence of tricyclohexylphosphine $\left(\mathrm{PCy}_{3}\right)$ and purified the amine by standard column chromatography (Figure 1a). ${ }^{13}$ In the presence of $5 \mathrm{~mol} \%$ of this amine, Suzuki-Miyaura coupling products were formed in high yields (Figure 1b). ${ }^{13}$ Their ICP-MS analysis showed $0.32 \mathrm{ppb}$ palladium in the reaction mixture. ${ }^{13}$ However, it was not clear to what "the solution" referred. We decided to investigate the reported coupling technology using our background in trace palladium detection methods. ${ }^{8,14-22}$

We prepared amine 1 according to the literature ${ }^{13}$ (Figure 1a) and purified the product by four rounds of column chromatography followed by recrystallization to prepare five batches. These five batches are called 1C1, 1-C2, 1-C3, 1-C4, and 1-RC, reflecting the number of times the material was subjected to column chromatography or recrystallization. 
a
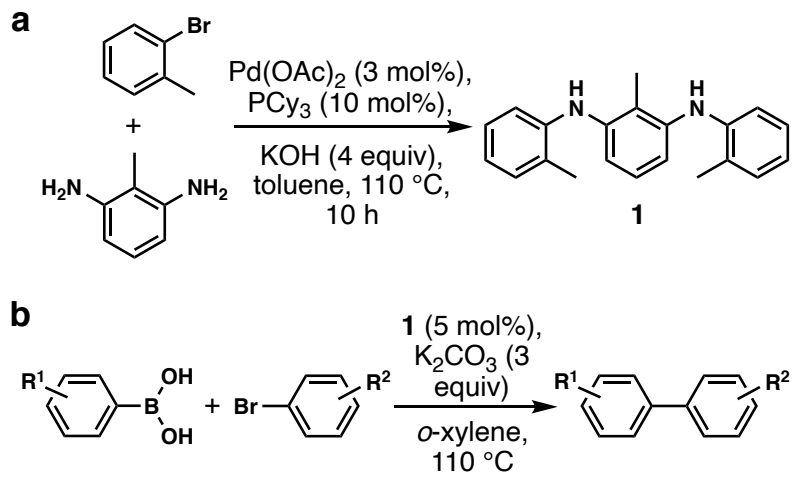

Figure 1. (a) Preparation of amine $1 .{ }^{13}$ (b) Suzuki-Miyaura coupling reported in the literature. ${ }^{13} \mathrm{Cy}$, cyclohexyl.

Our laboratory has developed a method to colorimetrically or fluorometrically quantify trace palladium in complex matrices, including synthetic organic materials. ${ }^{8,14-22}$ The technology proved to be sufficiently accurate in complex matrices when compared to other analytical techniques ${ }^{16-18,21,22}$ and is used in the pharmaceutical industry. ${ }^{19}$ The most recent variants of the technologies are the third ${ }^{21}$ and fourth ${ }^{22}$ generation methods. Although the fourth generation is more convenient, in this study we chose the third-generation method (Figure 2a) as the primary technique due to less likelihood of matrix interference. ${ }^{21}$ With this method, the palladium concentrations in samples 1-C1, 1-C2, 1-C3, 1-C4, and 1-RC were determined to be 65, 38, 12, 3.3, and $0.67 \mathrm{ppm}$ in their solid state (Figure 2, Table 1, and Table 2). A standard addition experiment was performed to validate this method (Supporting Information).

a

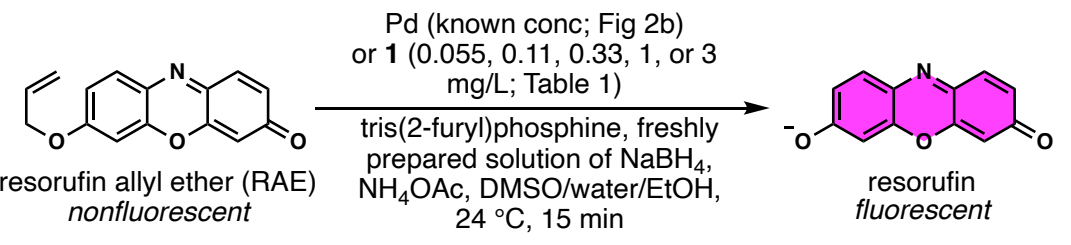

b

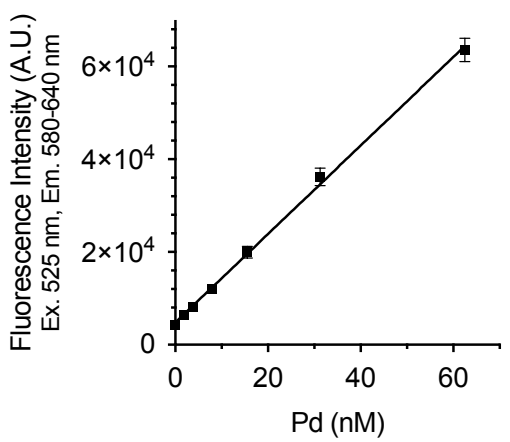

Figure 2, (a) Catalysis-based fluorometric method to quantify palladium. (b) Standard curve using the fluorometric method. Average \pm standard deviation values are shown. $y$-axis = fluorescence intensity (A.U.) at 15 min - fluorescence intensity (A.U.) at 0 min. Conditions: $60 \mu \mathrm{M} \mathrm{RAE}, 180 \mu \mathrm{M}$ tris(2-furyl)phosphine, $20 \mathrm{mM} \mathrm{NaBH}_{4}, 75 \mathrm{mM} \mathrm{NaOH}, 200 \mathrm{mM} \mathrm{NH}_{4} \mathrm{OAc}$, 8.7:17.0:74.3 v/v/v DMSO/water/EtOH, total volume $200 \mu \mathrm{L}$ per well, $24{ }^{\circ} \mathrm{C}, 15 \mathrm{~min} . n=3$. 
Table 1. Raw fluorescence data and calculated concentrations of palladium in five batches of amine 1 using the fluorescence method shown in Figure 2.

\begin{tabular}{|c|c|c|c|c|c|c|c|c|c|c|}
\hline \multirow[t]{2}{*}{$\begin{array}{l}\text { Conc } \\
\text { of } 1\end{array}$} & \multicolumn{2}{|l|}{$\begin{array}{c}3.0 \\
\mathrm{mg} / \mathrm{mL}\end{array}$} & \multicolumn{2}{|l|}{$\begin{array}{c}1.0 \\
\mathrm{mg} / \mathrm{mL}\end{array}$} & \multicolumn{2}{|c|}{$\begin{array}{c}0.33 \\
\mathrm{mg} / \mathrm{mL}\end{array}$} & \multicolumn{2}{|c|}{$\begin{array}{c}0.11 \\
\mathrm{mg} / \mathrm{mL}\end{array}$} & \multicolumn{2}{|c|}{$\begin{array}{c}0.055 \\
\mathrm{mg} / \mathrm{mL}\end{array}$} \\
\hline & F.I. & $\begin{array}{c}\mathrm{Pd} \\
(\mathrm{nM})\end{array}$ & F.I. & $\begin{array}{c}\mathrm{Pd} \\
(\mathrm{nM})\end{array}$ & F.I. & $\begin{array}{c}\mathrm{Pd} \\
(\mathrm{nM})\end{array}$ & F.I. & $\begin{array}{c}\mathrm{Pd} \\
(\mathrm{nM})\end{array}$ & F.I. & $\begin{array}{c}\mathrm{Pd} \\
(\mathrm{nM})\end{array}$ \\
\hline $1-C 1$ & N/A & - & N/A & - & 8.27 & 113 & 5.77 & 63 & 3.83 & 34 \\
\hline $1-C 2$ & N/A & - & N/A & - & 7.11 & 88 & 4.26 & 40 & 3.33 & 27 \\
\hline $1-\mathrm{C} 3$ & $\mathrm{~N} / \mathrm{A}$ & - & 8.35 & 114 & 4.05 & 37 & 1.85 & 12 & $\mathrm{~N} / \mathrm{A}$ & - \\
\hline 1-C4 & 8.17 & 110 & 3.65 & 31 & 1.57 & 9.1 & 0.849 & 3.8 & $\mathrm{~N} / \mathrm{A}$ & - \\
\hline 1-RC & 2.62 & 19 & 1.25 & 6.6 & $\mathrm{~N} / \mathrm{A}$ & - & $\mathrm{N} / \mathrm{A}$ & - & $\mathrm{N} / \mathrm{A}$ & - \\
\hline
\end{tabular}

F.I.: Fluorescence intensity $\left(\times 10^{4}\right)$

Data shown in bold fit in the linear range of the standard curve.

N/A: Not applicable because the fluorescence values were outside of the linear range.

Table 2. Palladium concentrations after normalizing the amine concentration to $1.0 \mathrm{mg} / \mathrm{mL}$ and those in amine 1 in solid state using the data in bold in Table 1.

\begin{tabular}{ccc}
\hline & $\begin{array}{c}\text { Pd in 1.0 mg/mL of 1 } \\
(\mathrm{nM})\end{array}$ & Pd in solid 1 (ppm) \\
\hline 1-C1 & 612 & 65 \\
1-C2 & 360 & 38 \\
1-C3 & 111 & 12 \\
1-C4 & 31 & 3.3 \\
1-RC & 6.3 & 0.67 \\
\hline
\end{tabular}

We performed the cross-coupling of $\mathrm{PhB}(\mathrm{OH})_{2}$ and 4-bromo-1,1'-biphenyl with 1-C2, 1-C3, 1-C4, and 1-RC (1-C1 was excluded due to fast kinetics) to reproduce the literature data (Figure 3a). ${ }^{13}$ Because the Xu group used $5 \mathrm{~mol} \%$ of amine 1 in most cases, we decided to use the same stoichiometry. Our preliminary study at $110{ }^{\circ} \mathrm{C}$ showed the reactions to be too fast to measure the initial rates. However, when the reactions were performed at $65^{\circ} \mathrm{C}$, the reaction rates were more tractable, yielding meaningful kinetic data. After 10, 20, 30, 45, 60, 75, and $120 \mathrm{~min}$, we analyzed the reaction progress by ${ }^{1} \mathrm{H}$ NMR spectroscopy with $\mathrm{Ph}_{3} \mathrm{CH}$ as an internal standard (Figure $3 \mathrm{~b}$ ). The product was undetectable when 1-RC was used at $65^{\circ} \mathrm{C}$. When the reaction mixture with 1-RC was heated to $110^{\circ} \mathrm{C}$ as shown in the original work terphenyl was generated in quantitative yield after $24 \mathrm{~h}$. We then plotted the concentrations of palladium in amine $\mathbf{1}$ in its solid state and the initial \% conversion per minute (Figure 3c). From these data, we conclude that the reaction rates are linearly correlated with the palladium contents $(\mathrm{P}<0.0015)$. During this study, two groups published their investigation on $\mathrm{Xu}$ 's paper and concluded that trace palladium was responsible for the catalysis. ${ }^{23,24}$ 
a

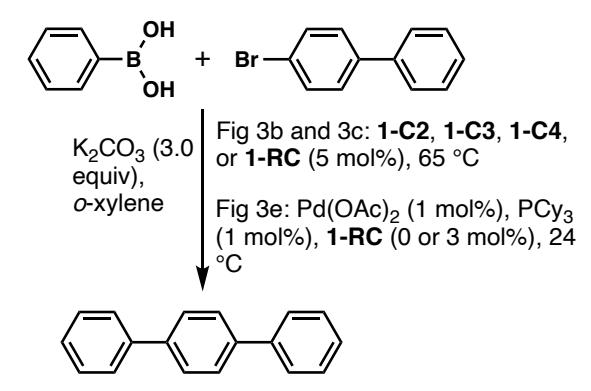

d

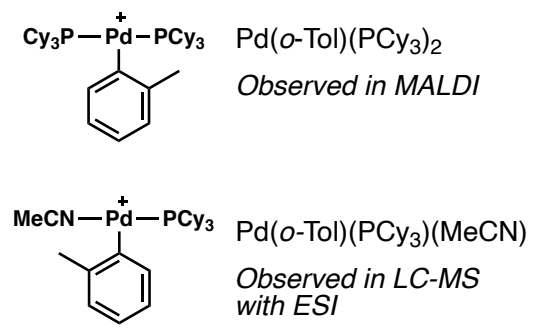

b

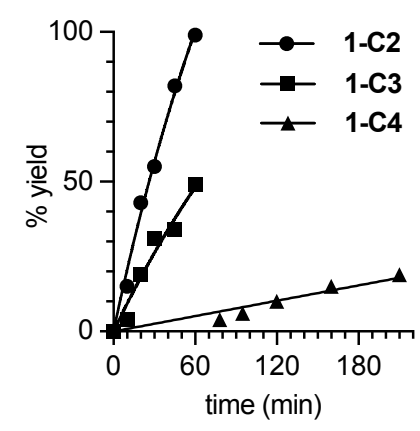

C

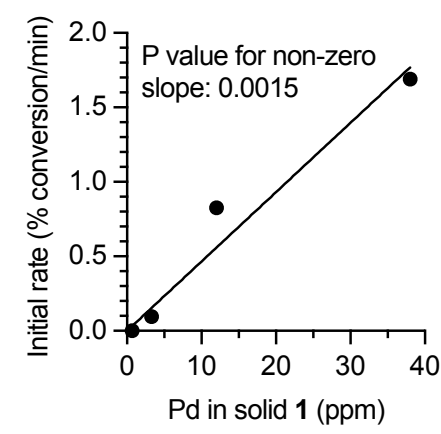

$\mathbf{e}$

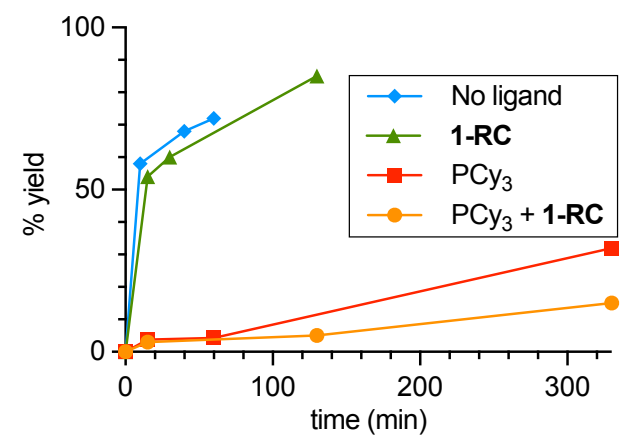

Figure 3. Suzuki-Miyaura coupling in the presence of amine 1. (a) Model coupling system. (b) Reaction kinetics in the presence of 1. (c) \% conversion per minute versus palladium concentrations in solid 1. (d) Structures of palladium complexes in amine 1 identified by MALDI and ESI with LC-MS using MeCN/water as eluent. (e) Suzuki-Miyaura coupling with palladium catalysis in the presence or absence of $\mathrm{PCy}_{3}$ or 1-RC.

The high-resolution mass spectroscopic data of 1-C2 showed the presence of palladium, as manifested by the characteristic isotope population for palladium (Spectrum S5, Supplementary Information). We propose that the palladium species in amine 1 may be $\mathrm{Pd}(o-\mathrm{Tol})\left(\mathrm{PCy}_{3}\right)_{2} \mathrm{X}(\mathrm{X}=\mathrm{Cl}$ or $\mathrm{Br})$ (Figure $\left.3 \mathrm{~d}\right)$, which was also identified by others. $^{24}$

While the catalytic activity of $\mathrm{Pd}(\mathrm{o}-\mathrm{Tol})(\mathrm{PCy})_{2} \mathrm{X}$ was shown to be high at $110{ }^{\circ} \mathrm{C},{ }^{24}$ the role of amine 1 to the coupling remains unclear. As a model system, we reacted $\mathrm{PhB}(\mathrm{OH})_{2}$ with 4-bromo-1,1'-biphenyl using 1 $\mathrm{mol} \% \mathrm{Pd}(\mathrm{OAc})_{2}$ and 3 equiv of $\mathrm{K}_{2} \mathrm{CO}_{3}$ in the presence of the following reagent(s) at room temperature: (1) no additive, (2) 3 mol\% 1-RC, (4) $1 \mathrm{~mol}_{\%} \mathrm{PCy}_{3}$, or (5) $1 \mathrm{~mol} \% \mathrm{PCy}_{3}$ and $3 \mathrm{~mol} \%$ 1-RC. Figure 3e shows that $\mathrm{PCy}_{3}$ retarded the reaction and that amine 1 had negligible effects. We reproduced the data for (1) no additive and (2) 3 mol\% 1-RC with two different batches of commercially available $\mathrm{Pd}(\mathrm{OAc})_{2}$ as shown in Figure S1. Although these data may not directly illuminate the role of amine 1 for the catalysis with $\mathrm{Pd}(o-\operatorname{Tol})(\mathrm{PCy})_{2} \mathrm{X}$, they may account for why elevated temperatures were needed when palladium-containing amine $\mathbf{1}$ was used for the coupling. ${ }^{13,23,24}$

In conclusion, this study shows that trace palladium in the purified batches of amine $\mathbf{1}$ was essential for Xu's results. The amount of palladium in Xu's work with 5 mol\% 1-C2 is at a homeopathic level ${ }^{25}$; specifically, 
the addition of $5 \mathrm{~mol} \%$ of amine 1 with $65 \mathrm{ppm}$ palladium means that approximately $9.3 \times 10^{-4} \mathrm{~mol} \%$ of palladium was present in the reaction mixture. In other words, the catalytic turnover number was at least 108 000 , suggesting that the trace palladium species was exceptionally reactive. Here, we compared palladium catalysis in the presence of amine $\mathbf{1}, \mathrm{PCy}_{3}$, and the combination of both, to find that $\mathrm{PCy}_{3}$ had an inhibitory effect, which is reminiscent of Norrby's work with aryl iodides ${ }^{26}$ and aryl chlorides. ${ }^{27}$ Without amine $\mathbf{1}$ or PCy, we could lower the reaction temperature from $110{ }^{\circ} \mathrm{C}$ to $24^{\circ} \mathrm{C}$ to carry out a ligand-free Suzuki-Miyaura coupling. ${ }^{28}$ Despite many ligand-free examples, Suzuki-Miyaura couplings as part of drug production continue to use phosphine ligands. ${ }^{29}$ The role of amine 1 with more complex substrates may warrant further study.

\section{Author Contributions}

K.K. conceived the study. J.K.V. prepared amine 1 and produced data shown in Figure 3. A.K.W. and E.I.J. produced data in Figure 2 and Table 1. All authors analyzed data.

\section{Acknowledgements}

This work was in part supported by the United States National Science Foundation (CHE-1955758). We thank Dr. Bhaskar Godugu (University of Pittsburgh) for acquiring high-resolution mass spectroscopic data. We thank Dr. Per-Ola Norrby (AstraZeneca) and Professor Robin Bedford (University of Bristol) for helpful discussions.

\section{Abbreviations}

Ac, acetyl; A.U., arbitrary unit; DMSO, dimethyl sulfoxide, Et, ethyl; g, gram; h, hour, Hz, hertz; M, molar; min, minutes; ppb, parts per billion; ppm, parts per million.

\section{Cited References}

1 Miyaura, N. \& Suzuki, A. Palladium-catalyzed cross-coupling reactions of organoboron compounds. Chem. Rev. 95, 2457-2483 (1995).

2 Leadbeater, N. E. \& Marco, M. Transition-metal-free Suzuki-type coupling reactions: Scope and limitations of the methodology. J. Org. Chem. 68, 5660-5667 (2003).

3 Leadbeater, N. E. \& Marco, M. Transition-metal-free Suzuki-type coupling reactions. Angew. Chem., Int. Ed. 42, 1407-1409 (2003).

4 Inamoto, K. et al. Use of dimethyl carbonate as a solvent greatly enhances the biaryl coupling of aryl iodides and organoboron reagents without adding any transition metal catalysts. Chem. Commun. 48, 2912-2914 (2012).

5 Leadbeater, N. E., Marco, M. \& Tominack, B. J. First examples of transition-metal free Sonogashira-type couplings. Org. Lett. 5, 3919-3922 (2003).

6 Thathagar, M. B., Beckers, J. \& Rothenberg, G. Palladium-free and ligand-free Sonogashira cross-coupling. Green Chem. 6, 215-218 (2004).

7 Arvela, R. K. et al. A reassessment of the transition-metal free Suzuki-type coupling methodology. J. Org. Chem. 70, 161-168 (2005).

8 Inamoto, K., Campbell, L. D., Doi, T. \& Koide, K. A highly sensitive fluorescence method reveals the presence of palladium in a cross-coupling reaction mixture not treated with transition metals. Tetrahedron Lett. 53, 3147-3148 (2012).

9 Gonda, Z., Tolnai, G. \& Novák, Z. Dramatic impact of ppb levels of palladium on the "copper-catalyzed" Sonogashira coupling. Chem.-Eur. J. 16, 11822-11826 (2010). 

catalyzed Sonogashira coupling reactions. Org. Lett. 12, 3006-3009 (2010).

11 Wang, R. P., Mo, S., Lu, Y. Z. \& Shen, Z. M. Domino Sonogashira coupling/cyclization reaction catalyzed by copper and ppb levels of palladium: A concise route to indoles and benzo[b]furans. Adv. Synth. Catal. 353, 713718 (2011).

12 Thomé, I., Nijs, A. \& Bolm, C. Trace metal impurities in catalysis. Chem. Soc. Rev. 41, 979-987 (2012).

13 Xu, L. et al. The amine-catalysed Suzuki-Miyaura-type coupling of aryl halides and arylboronic acids. Nat. Catal. 4, 71-78 (2021).

14 Song, F. L., Carder, E. J., Kohler, C. C. \& Koide, K. Studies toward an ideal fluorescence method to measure palladium in functionalized organic molecules: effects of sodium borohydride, temperature, phosphine ligand, and phosphate ions on kinetics. Chem.-Eur. J. 16, 13500-13508 (2010).

Li, D., Campbell, L. D., Austin, B. A. \& Koide, K. Detection of trace palladium in flasks and metal reagents using a fluorogenic Tsuji-Trost reaction. ChemPlusChem 77, 281-283 (2012). Bu, X. D., Koide, K., Carder, E. J. \& Welch, C. J. Rapid analysis of residual palladium in pharmaceutical development using a catalysis-based fluorometric method. Org. Process Res. Dev. 17, 108-113 (2013). Williams, J. M. \& Koide, K. A high-throughput method to detect palladium in ores. Ind. Eng. Chem. Res. 52, 8612-8615 (2013).

18 Koide, K. et al. A competitive and reversible deactivation approach to catalysis-based quantitative assays. Nat. Commun. 7, 10691 (2016).

19 Bu, X., Williams, M., Jo, J., Koide, K. \& Welch, C. J. Online sensing of palladium in flowing streams. Chem. Commun. 53, 720-723 (2017).

20 Nieberding, M., Tracey, M. P. \& Koide, K. Noneffervescent method for catalysis-based palladium detection with color or fluorescence. ACS Sens. 2, 1737-1743 (2017).

21 Lukomski, L., Pohorilets, I. \& Koide, K. Third-generation method for high-throughput quantification of trace palladium by color or fluorescence. Org. Process Res. Dev. 24, 85-95 (2020).

Williams, J. M., Wanner, A. K. \& Koide, K. Catalysis-Based Fluorometric Method for Trace Palladium Detection with Improved Convenience. Org. Process Res. Dev. 24, 2941-2949 (2020).

Zoltán, N. et al. Curse or Blessing? Influence of Impurities on Cross-Coupling - Guideline for Elucidating Catalysts. 10.26434/chemrxiv.14071247.v14071241 (2021).

24 Mickaël, A. et al. Amine-catalysed Suzuki-Miyaura-type coupling? The identification and isolation of the palladium culprits. 10.26434/chemrxiv.14237288.v14237281 (2021). de Vries, A. H. M., Mulders, J. M. C. A., Mommers, J. H. M., Henderickx, H. J. W. \& de Vries, J. G. Homeopathic ligand-free palladium as a catalyst in the Heck reaction. A comparison with a palladacycle. Org. Lett. 5, 3285-3288 (2003).

26 Ahlquist, M., Fristrup, P., Tanner, D. \& Norrby, P.-O. Theoretical evidence for low-ligated palladium(0): [Pd-L] as the active species in oxidative addition reactions. Organometallics 25, 2066-2073 (2006).

27 Ahlquist, M. \& Norrby, P.-O. Oxidative addition of aryl chlorides to monoligated palladium(0): A DFT-SCRF study. Organometallics 26, 550-553 (2007).

28 Hussain, I., Capricho, J. \& Yawer, M. A. Synthesis of biaryls via ligand-free Suzuki-Miyaura cross-coupling reactions: A review of homogeneous and heterogeneous catalytic developments. Adv. Synth. Catal. 358, 33203349 (2016).

29 Flick, A. C. et al. Synthetic approaches to the new drugs approved during 2019. J. Med. Chem. 64, 3604-3657 (2021). 


\title{
Supplementary Information
}

\section{On the amine-catalyzed Suzuki-Miyaura coupling using a catalysis-based fluorometric method}

\author{
Jincy K. Vinod, Annelise K. Wanner, Elizabeth I. James, and Kazunori Koide* \\ Department of Chemistry, University of Pittsburgh \\ 219 Parkman Avenue, Pittsburgh, Pennsylvania 15260, United States \\ koide@pitt.edu
}

\section{Table of Contents}

$\begin{array}{ll}\text { General Information and Reagents } & \text { S2 }\end{array}$

$\begin{array}{ll}\text { Preparation of amine } 1 & \text { S2 }\end{array}$

$\begin{array}{ll}\text { General Procedure for Kinetic study } & \text { S3 }\end{array}$

Procedure for Figure 2 (Quantification of palladium) S4

Method Validation Using Standard Addition $\quad$ S6

$\begin{array}{ll}\text { NMR Data } & \text { S8 }\end{array}$

$\begin{array}{ll}\text { Mass Spectroscopic Data } & \text { S11 }\end{array}$

$\begin{array}{lr}\text { Fluorescence Data } & \text { S14 }\end{array}$

$\begin{array}{ll}\text { Cited References } & \text { S15 }\end{array}$ 


\section{General Information and Reagents.}

Commercially available chemicals were purchased from Sigma-Aldrich or Alfa Aesar and used without further purification, unless otherwise indicated. Water used in this study was distilled. Reagent-grade DMSO was used without purification. Ethanol was USP-grade 200 proof. Trace-metal grade hydrochloric acid was purchased from Fisher. Resorufin allyl ether (RAE) ${ }^{1}$ was stored at ambient temperature away from light. Tris(2-furyl)phosphine (TFP) was purchased from Fisher, and its solutions in DMSO were stabilized by hydroquinone and stored at ambient temperature in amber vials. Sodium borohydride pellets $(1.00 \mathrm{~g}$ per pellet) were purchased from Fisher. A palladium standard solution was Atomic Absorption Spectroscopy (AAS) grade.

All the experiments were performed at ca. $24^{\circ} \mathrm{C}$ unless stated otherwise. Fluorescence data were acquired using black round-bottomed 96-well plates and a Promega Biosystems Modulus II Microplate Reader (excitation $525 \mathrm{~nm}$, emission 580-640 nm). GraphPad Prism 9.1.0 was used to generate graphs and perform statistical analyses.

Glassware was washed with $3 \% \mathrm{HCl}$ and flamed-dried immediately prior use or oven-dried $\left(80{ }^{\circ} \mathrm{C}\right.$, overnight). Solvents used for NMR spectroscopy were purchased from Cambridge Isotope Laboratories. $\mathrm{CDCl}_{3}$ was stored over anhydrous $\mathrm{K}_{2} \mathrm{CO}_{3}$. All ${ }^{1} \mathrm{H}$ NMR spectra were recorded on Bruker AVANCE III 300, 400, and 500 $\mathrm{MHz}$ spectrometers and calibrated using either tetramethylsilane or residual solvent peaks as internal reference. NMR yields were determined by ${ }^{1} \mathrm{H}$ NMR spectra of the crude reaction mixtures using $\mathrm{Ph}_{3} \mathrm{CH}$ as internal standard. Isolated yields refer to chromatographically purified materials, unless otherwise stated, and characterized by both NMR spectroscopy and high-resolution mass spectrometry (HRMS). The following abbreviations are used to indicate the multiplicities: s, singlet; d, doublet; t, triplet; q, quartet; m, multiplet; br, broad; app, apparent, or combinations thereof. HRMS data were obtained on a GCT, Micromass UK Ltd and Q-Tof Ultima API, Micromass UK Ltd. Reactions were monitored using thin-layer chromatography (TLC) or ${ }^{1} \mathrm{H}$ NMR spectroscopic analysis of crude material. SilicaFlash P60 (230-400 mesh) was used for flash chromatography after microwave treatment to remove water.

\section{Preparation of amine 1}

2-Methylbenzene 1,3-diamine (610 mg, $5.0 \mathrm{mmol}$ ), 1-bromo-2-methylbenzene (3.40 gg, $20.0 \mathrm{mmol}, 4.0$ equiv), $\mathrm{Pd}(\mathrm{OAc})_{2}$ (34 mg, $0.15 \mathrm{mmol}, 0.03$ equiv), and tricyclohexylphosphine (140 mg, $0.50 \mathrm{mmol}, 0.10$ equiv), $\mathrm{KOH}$ (1.12 g, $20.0 \mathrm{mmol}, 4.0$ equiv) were placed in a transparent Schlenk tube equipped with a stirring bar. Toluene $\left(25 \mathrm{~mL}\right.$ ) was added under a nitrogen atmosphere. The reaction mixture was stirred at $110^{\circ} \mathrm{C}$ (oil bath temperature) for $10 \mathrm{~h}$. The reaction mixture was cooled to room temperature, filtered through silica gel, and the filter cake was washed with EtOAc. The organic layers were combined and concentrated under vacuo. This procedure was repeated once, and the crude mixtures were combined. Glassware (column, flasks, and a bump trap for rotary evaporator) for the following column chromatography was washed with diluted $\mathrm{HCl}$ prior to use. The crude material was purified by flash column chromatography on silica gel $(120 \mathrm{~mL}$ silica, hexanes/EtOAc $=30: 1)$ to 
form 1-C1 (1.80 g, 63\%). Approximately $1.55 \mathrm{~g}$ of this batch was purified by column chromatography on silica gel $(100 \mathrm{~mL}$ silica, hexanes/EtOAc $=30: 1)$ to form 1-C2 $(1.5 \mathrm{~g})$. Approximately $1.25 \mathrm{~g}$ this batch was purified by column chromatography on silica gel $(100 \mathrm{~mL}$ silica, hexanes/EtOAc $=30: 1)$ to form 1-C3 $(1.25 \mathrm{~g})$. Lastly, approximately $950 \mathrm{mg}$ of this batch was purified by column chromatography on silica gel $(100 \mathrm{~mL}$ silica, hexanes/EtOAc $=30: 1)$ to form 1-C4 $(940 \mathrm{mg})$. A fraction of 1-C4 was recrystallized in EtOAc and hexanes to produce 1-RC (600 mg).

Data for amine 1: ${ }^{1} \mathrm{H}$ NMR $\left(300 \mathrm{MHz}, \mathrm{CDCl}_{3}\right) \delta 7.18(\mathrm{~d}, J=7.4 \mathrm{~Hz}, 2 \mathrm{H}), 7.10(\mathrm{t}, J=7.8 \mathrm{~Hz}, 2 \mathrm{H}), 7.04(\mathrm{t}$, $J=8.0 \mathrm{~Hz}, 2 \mathrm{H}), 6.87(\mathrm{~m}, 4 \mathrm{H}), 6.72(\mathrm{~d}, J=8.0 \mathrm{~Hz}, 2 \mathrm{H}), 2.28(\mathrm{~s}, 6 \mathrm{H}), 2.12(\mathrm{~s}, 3 \mathrm{H})$.$) . 2.28(\mathrm{~s}, 6 \mathrm{H}), 2.12(\mathrm{~s}, 3 \mathrm{H})$ HRMS (ESI) calcd for $\mathrm{C}_{12} \mathrm{H}_{23} \mathrm{~N}_{2}{ }^{+}\left[(\mathrm{M}+\mathrm{H})^{+}\right]$303.1856, Found 303.1851. The spectroscopic data matched those in the literature. ${ }^{2}$

\section{General Procedure for Kinetic Study}

\section{Method A (Figure 3b)}

An internal standard stock solution was prepared by mixing $\mathrm{Ph}_{3} \mathrm{CH}$ (1.5735 g, $6.4401 \mathrm{mmol}$ ) and biphenyl bromide $(1.5000 \mathrm{~g}, 6.4350 \mathrm{mmol})$ in $o$-xylene $(8.4 \mathrm{~mL})$. Phenylboronic acid (118 mg, $0.96 \mathrm{mmol}, 1.5 \mathrm{equiv}), 2-$ methyl- $N^{1}, N^{3}$-di-o-tolylbenzene-1,3-diamine 1 (10.0 mg, $0.03 \mathrm{mmol}, 0.05$ equiv) and $\mathrm{K}_{2} \mathrm{CO}_{3}$ (267 mg, $1.93 \mathrm{mmol}$, 3.0 equiv) were placed in a sealed tube equipped with a stirring bar. The stock solution $(1.2 \mathrm{~mL})$ was added under an argon atmosphere. The reaction mixture was stirred at $65^{\circ} \mathrm{C}$ for $5 \mathrm{~h}$. An aqueous workup with water/EtOAc on a small amount of reaction mixture was carried out in a vial. Organic layer was concentrated, dissolved in $\mathrm{CDCl}_{3}$, and transferred to an NMR tube. The yield was determined by comparing the peaks at $\delta 5.55\left(\mathrm{Ph}_{3} \mathrm{CH}\right)$ and $\delta 7.68$ (s, $4 \mathrm{H}$, terphenyl). The initial rates were calculated from the slopes of line with the zone of $0-20 \%$ conversion of terphenyl.

\section{Method B (Figure 3e)}

An internal standard stock solution was prepared by mixing triphenyl methane $(4.4000 \mathrm{~g}, 18.008 \mathrm{mmol})$ and biphenyl bromide $(4.2000 \mathrm{~g}, 18.018 \mathrm{mmol})$ in $o$-xylene $(34 \mathrm{~mL})$. The conversion of bromobiphenyl was obtained by comparing the peaks at $\delta 5.55\left(\mathrm{Ph}_{3} \mathrm{CH}\right)$ and $\delta 7.54-7.57(\mathrm{~m}, 4 \mathrm{H}$, bromobiphenyl).

Procedure I: Phenylboronic acid (471 mg, 3.86 mmol, 1.5 equiv), $\mathrm{K}_{2} \mathrm{CO}_{3}$ (1.0680 g, 7.7279 mmol, 3.0 equiv), $\mathrm{Pd}(\mathrm{OAc})_{2}(5.8 \mathrm{mg}, 0.02 \mathrm{mmol}, 1 \mathrm{~mol} \%), \mathrm{PCy}_{3}(7.2 \mathrm{mg}, 0.02 \mathrm{mmol}, 1 \mathrm{~mol} \%$ ), and amine 1-RC (23.3 $\mathrm{mg}$, $0.08 \mathrm{mmol}, 3 \mathrm{~mol} \%$ ) were placed in a $35-\mathrm{mL}$ sealed tube equipped with a stirring bar. The stock solution $(4.8 \mathrm{~mL})$ was added under an argon atmosphere. The reaction mixture was stirred at room temperature for $5 \mathrm{~h}$. An aqueous workup with water/EtOAc on a small amount of reaction mixture was carried out in a vial. Organic layer was concentrated, dissolved in $\mathrm{CDCl}_{3}$, and transferred to an NMR tube.

Procedure II: Phenylboronic acid (471 mg, 3.86 mmol, 1.5 equiv), $\mathrm{K}_{2} \mathrm{CO}_{3}$ (1.0680 g, 7.7279 mmol, 3.0 equiv.), $\mathrm{Pd}(\mathrm{OAc})_{2}(5.8 \mathrm{mg}, 0.02 \mathrm{mmol}, 1 \mathrm{~mol} \%$ ), and amine 1-RC (23.3 mg, $0.08 \mathrm{mmol}, 3 \mathrm{~mol} \%$ ) were placed in a $35-\mathrm{mL}$ sealed tube equipped with a stirring bar. The stock solution $(4.8 \mathrm{~mL})$ was added under an argon 
atmosphere. The reaction mixture was stirred at room temperature for $5 \mathrm{~h}$. An aqueous workup with water/EtOAc on a small amount of reaction mixture was carried out in a vial. Organic layer was concentrated, dissolved in $\mathrm{CDCl}_{3}$, and transferred to an NMR tube.

Procedure III: Phenylboronic acid (471 mg, 3.86 mmol, 1.5 equiv), $\mathrm{K}_{2} \mathrm{CO}_{3}$ (1.0680 g, 7.7279 mmol, 3.0 equiv), $\mathrm{Pd}(\mathrm{OAc})_{2}(5.8 \mathrm{mg}, 0.02 \mathrm{mmol}, 1 \mathrm{~mol} \%)$ and $\mathrm{PCy}_{3}(7.2 \mathrm{mg}, 0.02 \mathrm{mmol}, 1 \mathrm{~mol} \%$ ) were placed in a $35-\mathrm{mL}$ sealed tube equipped with a stirring bar. The stock solution $(4.8 \mathrm{~mL})$ was added under an argon atmosphere. The reaction mixture was stirred at room temperature for $5 \mathrm{~h}$. An aqueous workup with water/EtOAc on a small amount of reaction mixture was carried out in a vial. Organic layer was concentrated, dissolved in $\mathrm{CDCl}_{3}$, and transferred to an NMR tube.

Procedure IV: Phenylboronic acid (471 mg, 3.86 mmol, 1.5 equiv), $\mathrm{K}_{2} \mathrm{CO}_{3}$ (1.0680 g, 7.7279 mmol, 3.0 equiv.), and $\mathrm{Pd}(\mathrm{OAc})_{2}(5.8 \mathrm{mg}, 0.02 \mathrm{mmol}, 1 \mathrm{~mol} \%$ ) were placed in a $35-\mathrm{mL}$ sealed tube equipped with a stirring bar. The stock solution $(4.8 \mathrm{~mL})$ was added under an argon atmosphere. The reaction mixture was stirred at room temperature for $5 \mathrm{~h}$. An aqueous workup with water/EtOAc on a small amount of reaction mixture was carried out in a vial. Organic layer was concentrated, dissolved in $\mathrm{CDCl}_{3}$, and transferred to an $\mathrm{NMR}$ tube.

\section{Study on the role of Amine in Suzuki-Miyaura coupling at room temperature}

Figure S1 was obtained by repeating Procedure II and IV using two different batches of commercially available $\mathrm{Pd}(\mathrm{OAc})_{2}$.

Figure S1. Suzuki-Miyaura coupling with palladium catalysis in the presence or absence of 1-RC

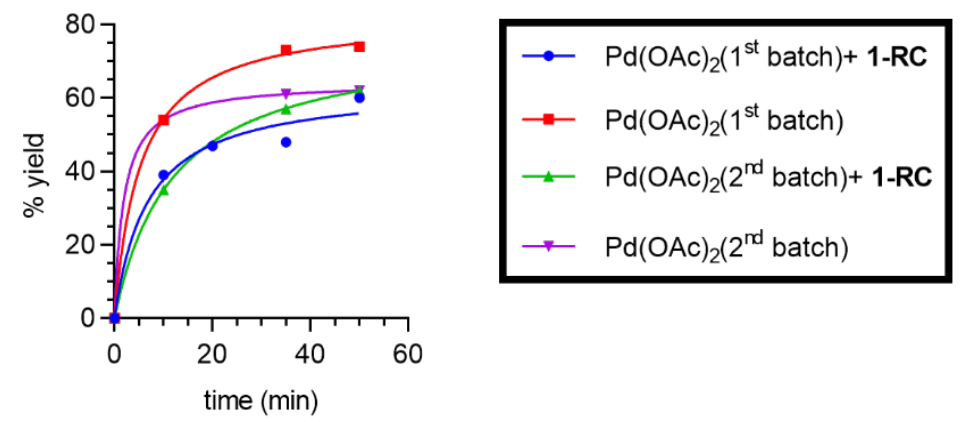

\section{Procedure for Figure 2 (Quantification of palladium)}

Preparation of $85.7 \mu \mathrm{M} \mathrm{RAE} / 286 \mathrm{mM} \mathrm{NH}_{4} \mathrm{OAc}$ in 10.7:89.3 v/v DMSO/EtOH: (1) RAE (25.3 mg) was dissolved in DMSO (20.00 mL) in an amber vial to prepare 5.0 mM RAE in DMSO. (2) An aliquot of this solution (8.0 mL) was diluted with EtOH $(42.0 \mathrm{~mL})$ in an amber bottle to prepare $800 \mu \mathrm{M} \mathrm{RAE}$ in 4:21 v/v DMSO/EtOH solution. (3) The $800 \mu \mathrm{M}$ RAE solution in DMSO (32.14 mL) was mixed with $500 \mathrm{mM} \mathrm{NH}_{4} \mathrm{OAc}(171.6 \mathrm{~mL})$ and EtOH (96.26 mL). The resulting solutions were stored at $-20^{\circ} \mathrm{C}$. 
Preparation of $15.0 \mathrm{mM}$ TFP in DMSO: Butylated hydroxytoluene (BHT, $12.5 \mathrm{mg}$ ) was dissolved in DMSO $(50 \mathrm{~mL})$ in an amber bottle to prepare $250 \mathrm{ppm}$ BHT in DMSO. The BHT solution in DMSO $(6.667 \mathrm{~mL})$ was used to dissolve TFP $(23.2 \mathrm{mg}, 100 \mu \mathrm{mol})$ in an amber bottle to prepare $15.0 \mathrm{mM}$ TFP in DMSO. The resulting solution can be stored at room temperature for at least 6 months.

Preparation of $2.0 \mathrm{mM}$ Pd solution in trace metal HCl: (1) $1000 \mathrm{ppm} \mathrm{Pd}$ in 10\% $\mathrm{HCl}(240 \mu \mathrm{L})$ was diluted with $0.7 \mathrm{M}$ trace metal $\mathrm{HCl}$ in water $(896 \mu \mathrm{L})$ to prepare $2.0 \mathrm{mM} \mathrm{Pd}$ solution, which can be stored for at least 3 months.

Preparation of Pd samples: (1) $0.50 \mathrm{M} \mathrm{HCl}$ in 1:4 v/v DMSO/water was prepared (solution A). (2) A solution of $2.0 \mathrm{mM} \mathrm{Pd}$ in $3 \% \mathrm{HCl}$ was 10 -fold serially diluted twice $(200 \mu \mathrm{L})$ with solution $\mathbf{A}(1.800 \mu \mathrm{L})$ to prepare $200 \mu \mathrm{M}$ and $20 \mu \mathrm{M}$ Pd. (3) The $20 \mu \mathrm{M}$ Pd (1000 $\mu \mathrm{L})$ was 2-fold serially diluted ten times with solution A $(1000 \mu \mathrm{L})$ to prepare $19.5,39,78,156,313,625,1250,2500,5000,10000,20000 \mathrm{nM}$ Pd in solution A. Solution A was used as $0 \mathrm{nM}$ Pd. Pd solutions were discarded after $12 \mathrm{~h}$.

Preparation of $2.67 \mathrm{M} \mathrm{NaBH}_{4}$ and $10 \mathrm{M} \mathrm{NaOH}$ : One $\mathrm{NaBH}_{4}$ pellet (1.00 g, $\left.26.4 \mathrm{mmol}\right)$ was dissolved in cold aqueous $10 \mathrm{M} \mathrm{NaOH}(9.91 \mathrm{~mL})$ to prepare $2.67 \mathrm{M} \mathrm{NaBH}_{4}$ and $10 \mathrm{M} \mathrm{NaOH}$ in water. The solution was kept on ice for up to $8 \mathrm{~h}$ (this solution should be prepared within $8 \mathrm{~h}$ prior to use. CAUTION: Do not store the solution in a refrigerator due to the gradual evolution of hydrogen gas.

Preparation of amine samples for palladium analysis: (1) Amine 1-C1, 1-C2, 1-C3, 1-C4, and 1-RC (5.00 mg each) were weighed using a precise analytical balance into clear glass vials. (2) The samples were dissolved in DMSO to prepare $5.0 \mathrm{mg} / \mathrm{mL}$ solutions. (3) These solutions $(600 \mu \mathrm{L})$ were diluted with $625 \mathrm{mM} \mathrm{HCl}$ $(400 \mu \mathrm{L})$ to prepare $3.0 \mathrm{mg} / \mathrm{mL}$ solutions of 1-C1, 1-C2, 1-C3, 1-C4, and 1-RC. (4) Three rounds of 3-fold serial dilutions were performed with $300 \mu \mathrm{L}$ of sample and $600 \mu \mathrm{L}$ of solution $\mathbf{A}$ to prepare $1,0.33$, and $0.11 \mathrm{mg} / \mathrm{mL}$ solutions of 1-C1, 1-C2, 1-C3, 1-C4, and 1-RC. (5) With 1-C1 and 1-C2 samples, a 2-fold dilution of $0.11 \mathrm{mg} / \mathrm{mL}$ sample $(300 \mu \mathrm{L})$ with solution $\mathbf{A}(300 \mu \mathrm{L})$ was performed to prepare $0.055 \mathrm{mg} / \mathrm{mL}$ solutions of 1-C1 and 1-C2.

Preparation of $900 \mu \mathrm{M}$ TFP/100 $\mathrm{mM} \mathrm{NaBH}_{4} / 375 \mathrm{mM} \mathrm{NaOH}$ in 6:44:50 v/v/v DMSO/EtOH/water: (1) The $2.67 \mathrm{M} \mathrm{NaBH}_{4}$ and $10 \mathrm{M} \mathrm{NaOH}$ in water $(1.80 \mathrm{~mL})$ was diluted with water $(10.20 \mathrm{~mL})$ in a $15 \mathrm{~mL}$ conical centrifuge tube to prepare $400 \mathrm{mM} \mathrm{NaBH}_{4}$ and $1.5 \mathrm{M} \mathrm{NaOH}$ in water. (2) This solution (3.00 mL), cold EtOH $(5.28 \mathrm{~mL}), 15.0 \mathrm{mM}$ TFP in DMSO $(720 \mu \mathrm{L})$, and water $(3.00 \mathrm{~mL})$ were mixed in a reservoir to prepare $900 \mu \mathrm{M}$ $\mathrm{TFP} / 100 \mathrm{mM} \mathrm{NaBH}_{4} / 375 \mathrm{mM} \mathrm{NaOH}$ in 6:44:50 v/v DMSO/EtOH/water.

Assay: Final conditions: $180 \mu \mathrm{M}$ TFP, $60 \mu \mathrm{M} \mathrm{RAE}, 20 \mathrm{mM} \mathrm{NaBH}_{4}, 75 \mathrm{mM} \mathrm{NaOH}, 200 \mathrm{mM} \mathrm{NH}_{4} \mathrm{OAc}$, 8.7:17.0:74.3 v/v DMSO/water/EtOH, total volume $200 \mu \mathrm{L}$ per well, $24{ }^{\circ} \mathrm{C}, n=3$. (1) A solution of $85.7 \mu \mathrm{M}$ $\mathrm{RAE} / 286 \mathrm{mM} \mathrm{NH}_{4} \mathrm{OAc}$ in 10.7:89.3 v/v DMSO/EtOH (140 $\left.\mu \mathrm{L}\right)$ was transferred to wells in a black 96-well plate. (2) A solution of $0,19.6,39.1,78.1,156,313,625,1250,2500$, or $5000 \mathrm{nM} \mathrm{Pd}(20 \mu \mathrm{L})$ was transferred to wells for correlation curve. (3) Samples 1-C1, 1-C2, 1-C3, 1-C4, and 1-RC at concentrations 3.0-0.055 mg/mL (20 $\mu \mathrm{L})$ were transferred to wells. (4) A solution of $900 \mu \mathrm{M}$ TFP/100 mM NaBH$/ 4 / 375 \mathrm{mM} \mathrm{NaOH}$ in $6: 44: 50 \mathrm{v} / \mathrm{v} / \mathrm{v}$ 
DMSO/EtOH/water solution (40 $\mu \mathrm{L})$ was transferred to wells. (4) Fluorescence measured every 15 min for 60 min. (5) $F_{15 \min }-F_{0 \min }$ values were calculated.

\section{Method Validation Using Standard Addition}

Preparation of 85.7 $\mu \mathrm{M}$ RAE/286 $\mathrm{mM} \mathrm{NH}_{4} \mathrm{OAc}$ in 10.7:89.3 v/v DMSO/EtOH: (1) RAE (25.3 mg) was dissolved in DMSO (20.00 mL) in an amber vial to prepare 5.0 mM RAE in DMSO. (2) An aliquot of this solution $(8.0 \mathrm{~mL})$ was diluted with EtOH (42.0 mL) in an amber bottle to prepare $800 \mu \mathrm{M} \mathrm{RAE}$ in 4:21 v/v DMSO/EtOH solution. (3) The $800 \mu \mathrm{M}$ RAE solution in DMSO (32.14 mL) was mixed with $500 \mathrm{mM} \mathrm{NH} 4 \mathrm{OAc}(171.6 \mathrm{~mL})$ and $\mathrm{EtOH}$ $(96.26 \mathrm{~mL})$. The resulting solutions were stored at $-20^{\circ} \mathrm{C}$.

Preparation of $15.0 \mathrm{mM}$ TFP in DMSO: Butylated hydroxytoluene (BHT, $12.5 \mathrm{mg}$ ) was dissolved in DMSO $(50 \mathrm{~mL})$ in an amber bottle to prepare $250 \mathrm{ppm}$ BHT in DMSO. The BHT solution in DMSO $(6.667 \mathrm{~mL})$ was used to dissolve TFP $(23.2 \mathrm{mg}, 100 \mu \mathrm{mol})$ in an amber bottle to prepare $15.0 \mathrm{mM}$ TFP in DMSO. The resulting solution can be stored at room temperature for at least 6 months.

Preparation of $2.0 \mathrm{mM}$ Pd solution in trace metal HCl: (1) $1000 \mathrm{ppm} \mathrm{Pd}$ in $10 \% \mathrm{HCl}(240 \mu \mathrm{L})$ was diluted with $0.7 \mathrm{M}$ trace metal $\mathrm{HCl}$ in water $(896 \mu \mathrm{L})$ to prepare $2.0 \mathrm{mM}$ Pd solution, which can be stored for at least 3 months.

Preparation of Pd samples: (1) $0.50 \mathrm{M} \mathrm{HCl}$ in 1:4 v/v DMSO/water was prepared (solution A). (2) A solution of $2.0 \mathrm{mM} \mathrm{Pd}$ in $3 \% \mathrm{HCl}$ was 10 -fold serially diluted twice $(200 \mu \mathrm{L})$ with solution $\mathbf{A}(1.800 \mu \mathrm{L})$ to prepare $200 \mu \mathrm{M}$ and $20 \mu \mathrm{M}$ Pd. (3) The $20 \mu \mathrm{M}$ Pd (1000 $\mu \mathrm{L})$ was 2-fold serially diluted ten times with solution $\mathbf{A}(1000 \mu \mathrm{L})$ to prepare $19.5,39,78,156,313,625,1250,2500,5000,10000,20000 \mathrm{nM}$ Pd in solution A. Solution A was used as $0 \mathrm{nM}$ Pd. Pd solutions were discarded after $12 \mathrm{~h}$.

Preparation of 2.67 $\mathrm{M} \mathrm{NaBH}_{4}$ and $10 \mathrm{M} \mathrm{NaOH}$ : One $\mathrm{NaBH}_{4}$ pellet (1.00 g, $\left.26.4 \mathrm{mmol}\right)$ was dissolved in cold aqueous $10 \mathrm{M} \mathrm{NaOH}(9.91 \mathrm{~mL})$ to prepare $2.67 \mathrm{M} \mathrm{NaBH}_{4}$ and $10 \mathrm{M} \mathrm{NaOH}$ in water. The solution was kept on ice for up to $8 \mathrm{~h}$ (this solution should be prepared within $8 \mathrm{~h}$ prior to use. CAUTION: Do not store the solution in a refrigerator due to the gradual evolution of hydrogen gas.

Preparation of amine samples for palladium analysis: (1) Amine 1-C3 (5.00 mg) was weighed using a precise analytical balance into a clear glass vial. (2) The sample was dissolved in DMSO to prepare a $5.0 \mathrm{mg} / \mathrm{mL}$ solution. (3) This solution $(600 \mu \mathrm{L})$ was diluted with $625 \mathrm{mM} \mathrm{HCl}(400 \mu \mathrm{L})$ to prepare a $3.0 \mathrm{mg} / \mathrm{mL}$ solution of 1-C3. (4) Two rounds of 3-fold serial dilutions were performed with $300 \mu \mathrm{L}$ of sample and $600 \mu \mathrm{L}$ of solution $\mathbf{A}$ to prepare 1 and $0.33 \mathrm{mg} / \mathrm{mL}$ solutions of $\mathbf{1 - C 3}$.

Preparation of $900 \mu \mathrm{MTFP} / 100 \mathrm{mM} \mathrm{NaBH}_{4} / 375 \mathrm{mM} \mathrm{NaOH}$ in 6:44:50 v/v/v DMSO/EtOH/water: (1) The $2.67 \mathrm{M} \mathrm{NaBH}_{4}$ and $10 \mathrm{M} \mathrm{NaOH}$ in water $(1.80 \mathrm{~mL})$ was diluted with water $(10.20 \mathrm{~mL})$ in a $15 \mathrm{~mL}$ conical centrifuge tube to prepare $400 \mathrm{mM} \mathrm{NaBH}_{4}$ and $1.5 \mathrm{M} \mathrm{NaOH}$ in water. (2) This solution (3.00 mL), cold EtOH $(5.28 \mathrm{~mL}), 15.0 \mathrm{mM}$ TFP in DMSO $(720 \mu \mathrm{L})$, and water $(3.00 \mathrm{~mL})$ were mixed in a reservoir to prepare $900 \mu \mathrm{M}$ $\mathrm{TFP} / 100 \mathrm{mM} \mathrm{NaBH} / 475 \mathrm{mM} \mathrm{NaOH}$ in 6:44:50 v/v DMSO/EtOH/water. 
Assay: Final conditions: $0.33 \mathrm{mg} / \mathrm{mL}$ amine 1-C3, $171 \mu \mathrm{M}$ TFP, $57 \mu \mathrm{M}$ RAE, $19 \mathrm{mM} \mathrm{NaBH}_{4}, 71 \mathrm{mM}$ $\mathrm{NaOH}, 190 \mathrm{mM} \mathrm{NH}_{4} \mathrm{OAc}$, 8.7:17.0:74.3 v/v DMSO/water/EtOH, 0, 7.43, or $59.5 \mathrm{nM}$ Pd spike, total volume $210 \mu \mathrm{L}$ per well, $24{ }^{\circ} \mathrm{C}, n=2$ or 3 . (1) A solution of $85.7 \mu \mathrm{M} \mathrm{RAE} / 286 \mathrm{mM} \mathrm{NH}_{4} \mathrm{OAc}$ in 10.7:89.3 v/v DMSO/EtOH $(140 \mu \mathrm{L})$ was transferred to columns 1-3, rows A-C in a black 96-well plate. (2) Sample 1-C3 at concentration $0.33 \mathrm{mg} / \mathrm{mL}(20 \mu \mathrm{L})$ was transferred to columns 1-3, rows A-C. (3) 1250, 156, and $0 \mathrm{nM} \mathrm{Pd}$ solutions $(10 \mu \mathrm{L})$ were transferred to rows A-C, respectively. (4) A solution of $900 \mu \mathrm{M} \mathrm{TFP} / 100 \mathrm{mM}$ $\mathrm{NaBH}_{4} / 375 \mathrm{mM} \mathrm{NaOH}$ in 6:44:50 v/v/v DMSO/EtOH/water solution $(40 \mu \mathrm{L})$ was transferred to wells. (4) Fluorescence measured every $15 \mathrm{~min}$ for $60 \mathrm{~min}$. (5) $\mathrm{F}_{15 \min }-\mathrm{F}_{0 \min }$ values were calculated.

Figure S2. Standard addiction. The $\mathrm{y}$-axis is $\mathrm{F}_{15 \min }-\mathrm{F}_{0 \mathrm{~min}}$. Data are means \pm standard deviation. $n=2$ or 3 . The $\mathrm{x}$-intercept of the red line can be extrapolated, which represents the concentration of $\mathrm{Pd}$ in $0.33 \mathrm{mg} / \mathrm{mL}$ amine 1-C3 without any added palladium. In the main text, the palladium concentration in $0.33 \mathrm{mg} / \mathrm{mL} \mathbf{1 - C} 3$ was determined to be $37 \mathrm{nM}$. The red line shows that the standard addition experiment indicates $36 \mathrm{nM}$.

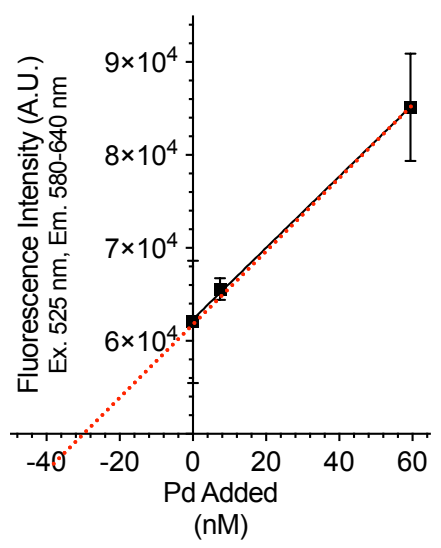


Spectrum S1. ${ }^{1} \mathrm{H}$ NMR spectrum of amine $1\left(300 \mathrm{MHz}, \mathrm{CDCl}_{3}, 298 \mathrm{~K}\right)$

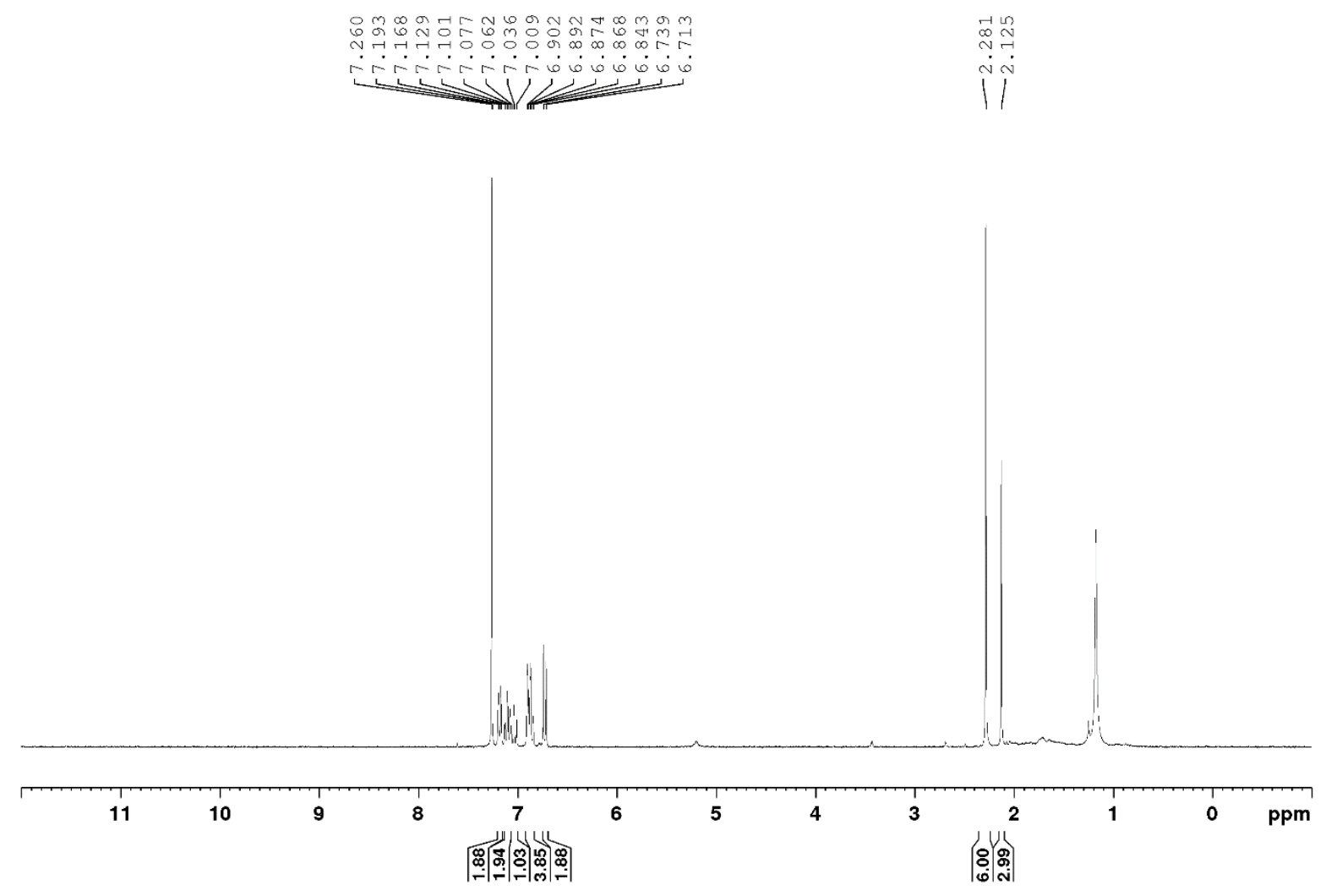


Spectrum S2. Representative ${ }^{1} \mathrm{H}$ NMR spectrum of crude mixture for kinetic experiments in Figure $3 \mathrm{~b}$ $\left(400 \mathrm{MHz}, \mathrm{CDCl}_{3}, 298 \mathrm{~K}\right)$

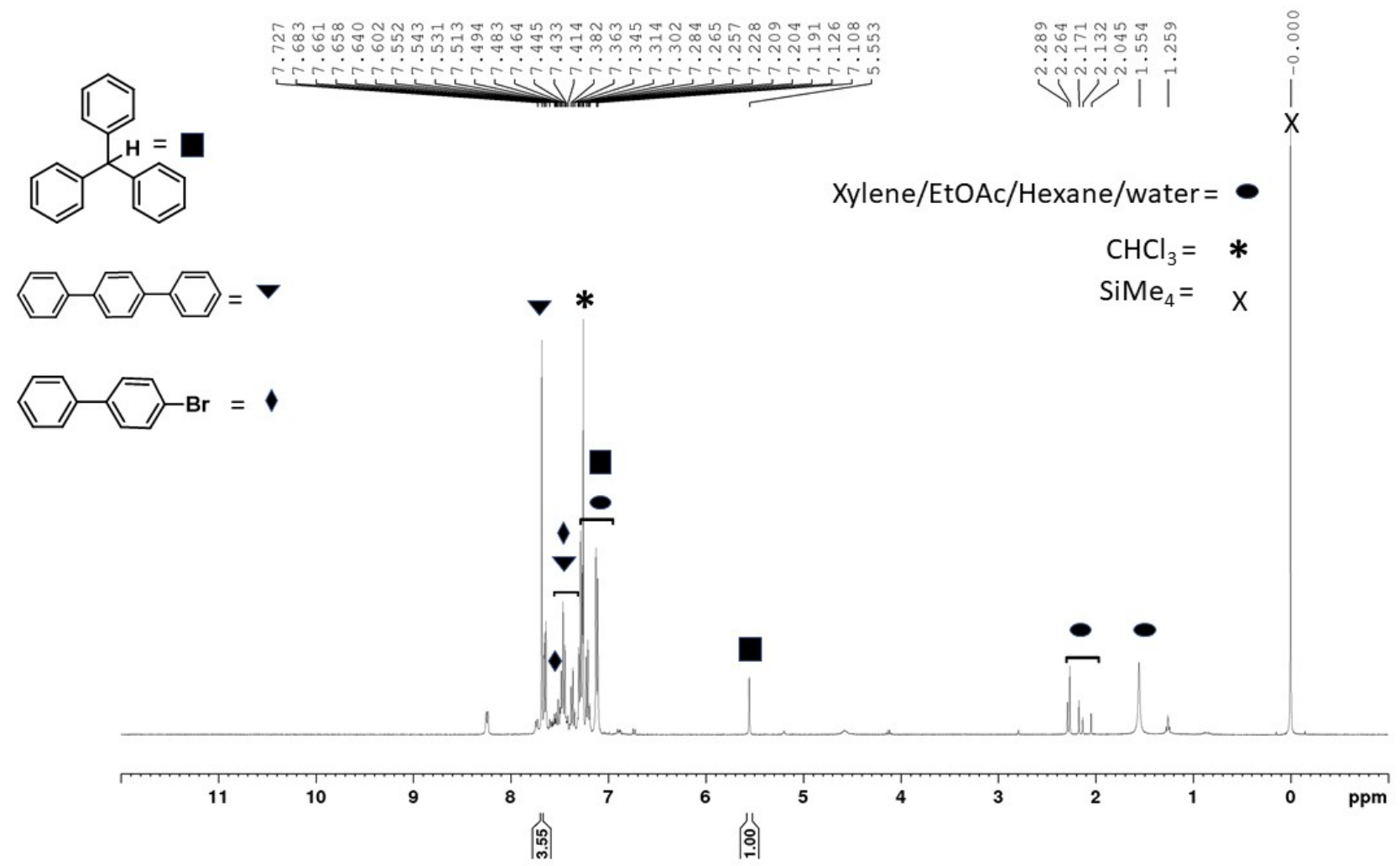

Spectrum S3. Representative ${ }^{1} \mathrm{H}$ NMR spectrum of crude mixture for kinetic experiments in Figure $3 \mathrm{e}$ (400 MHz, $\mathrm{CDCl}_{3}, 298 \mathrm{~K}$ )
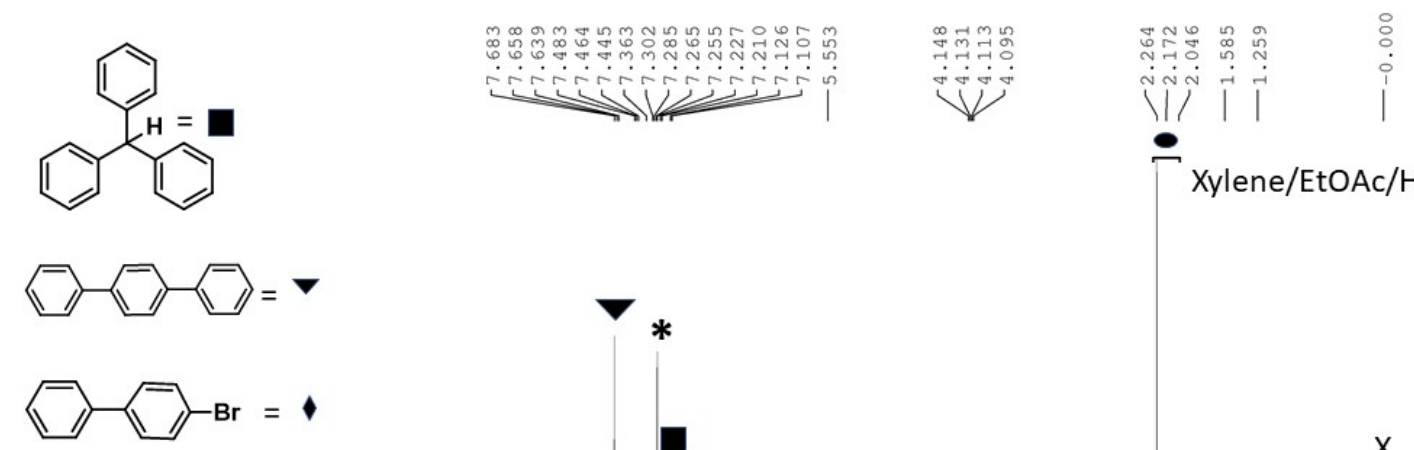

Xylene/EtOAc/Hexane/water $=$

$\mathrm{CHCl}_{3}=*$

$\mathrm{SiMe}_{4}=\mathrm{x}$ 
Spectrum S4. Representative ${ }^{1} \mathrm{H}$ NMR spectrum of crude mixture for kinetic experiments in Figure S1 (400 MHz, $\mathrm{CDCl}_{3}, 298 \mathrm{~K}$ )

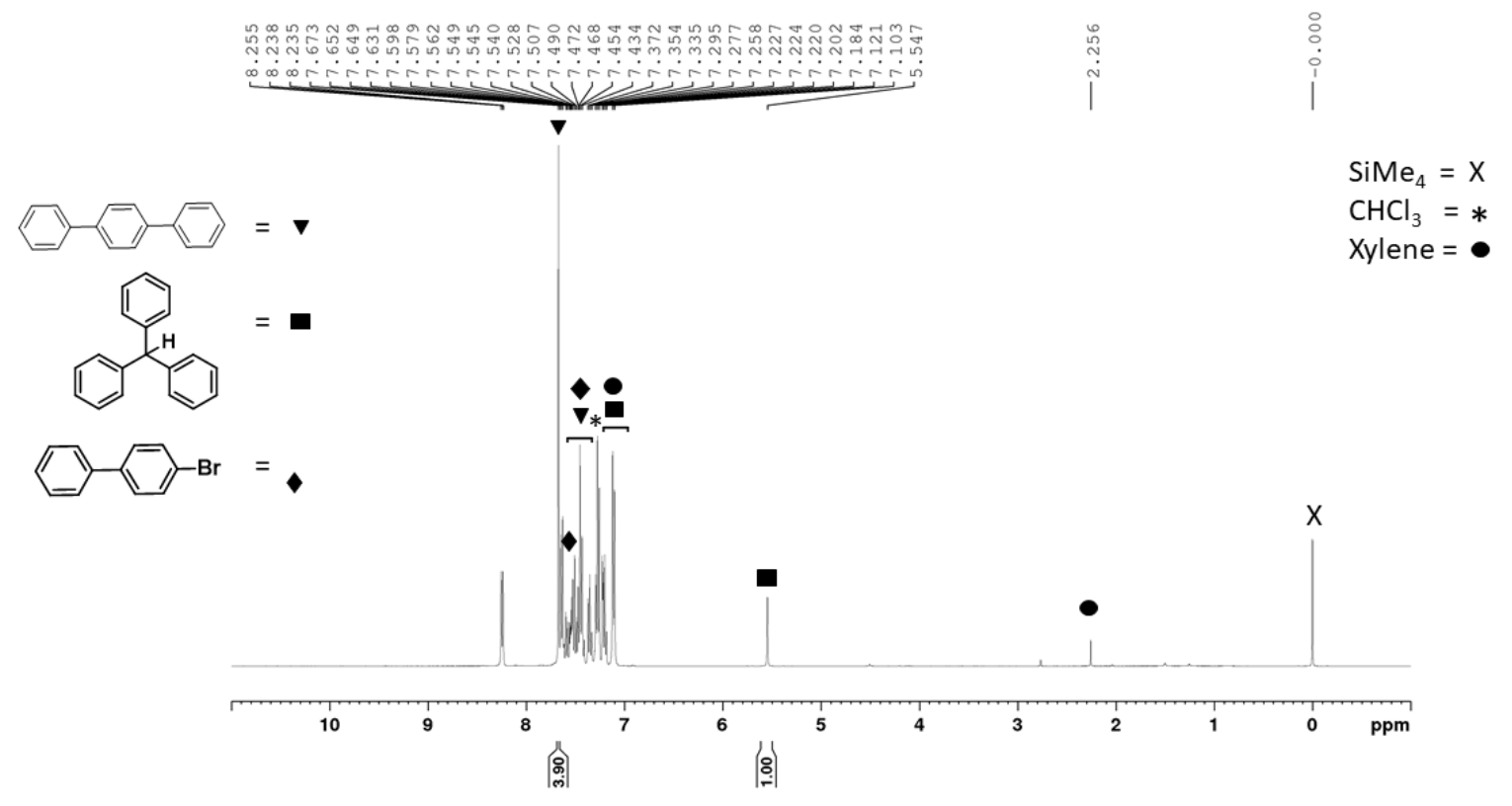




\section{Spectrum S4. LCMS Spectrum of 1-C3 for Figure 3d}

RT: $0.00-30.02$ SM: 11B

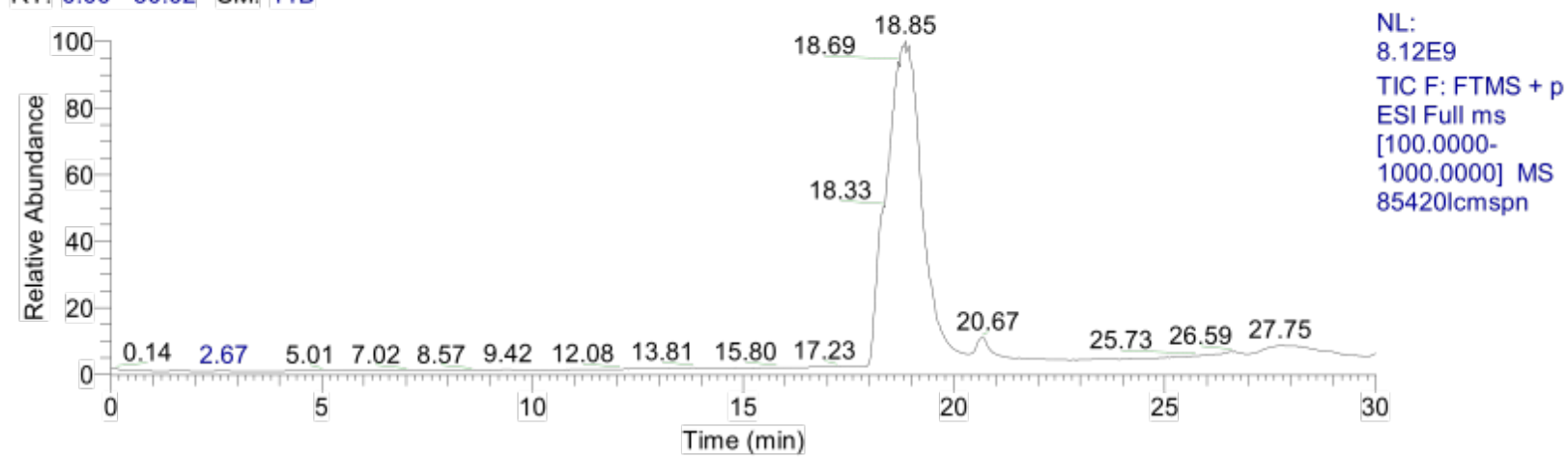

85420lcmspn \#1601-1732 RT: 18.06-19.41 AV: 66 NL: $3.54 E 9$

T: FTMS + p ESI Full ms [100.0000-1000.0000]

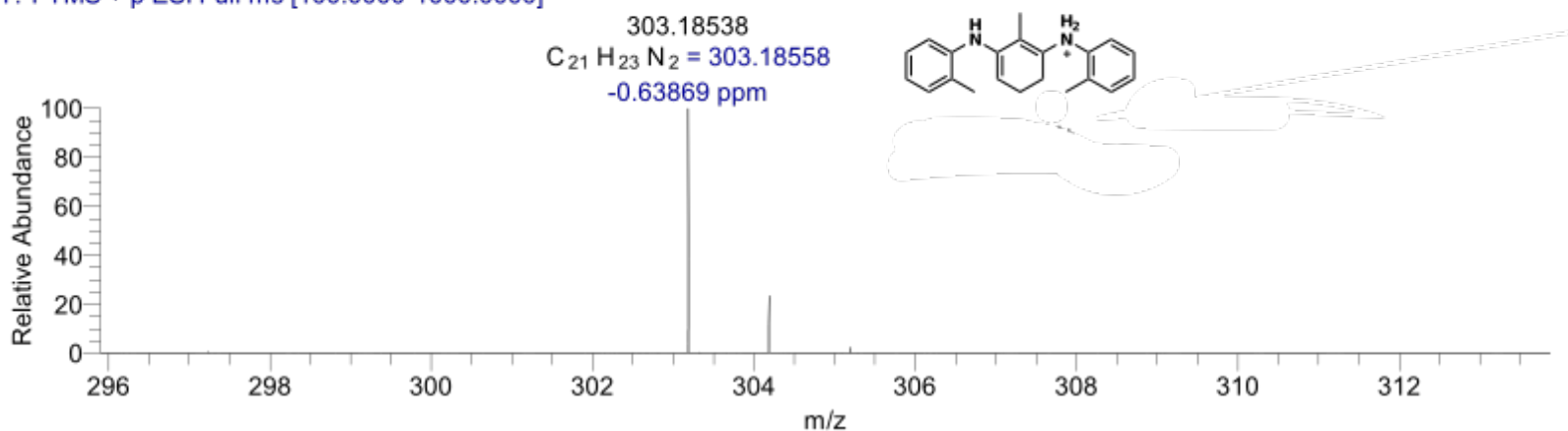

85420lcmspn \#1822-1888 RT: 20.39-21.07 AV: 33 NL: $5.22 E 7$

T: FTMS + p ESI Full ms [100.0000-1000.0000]
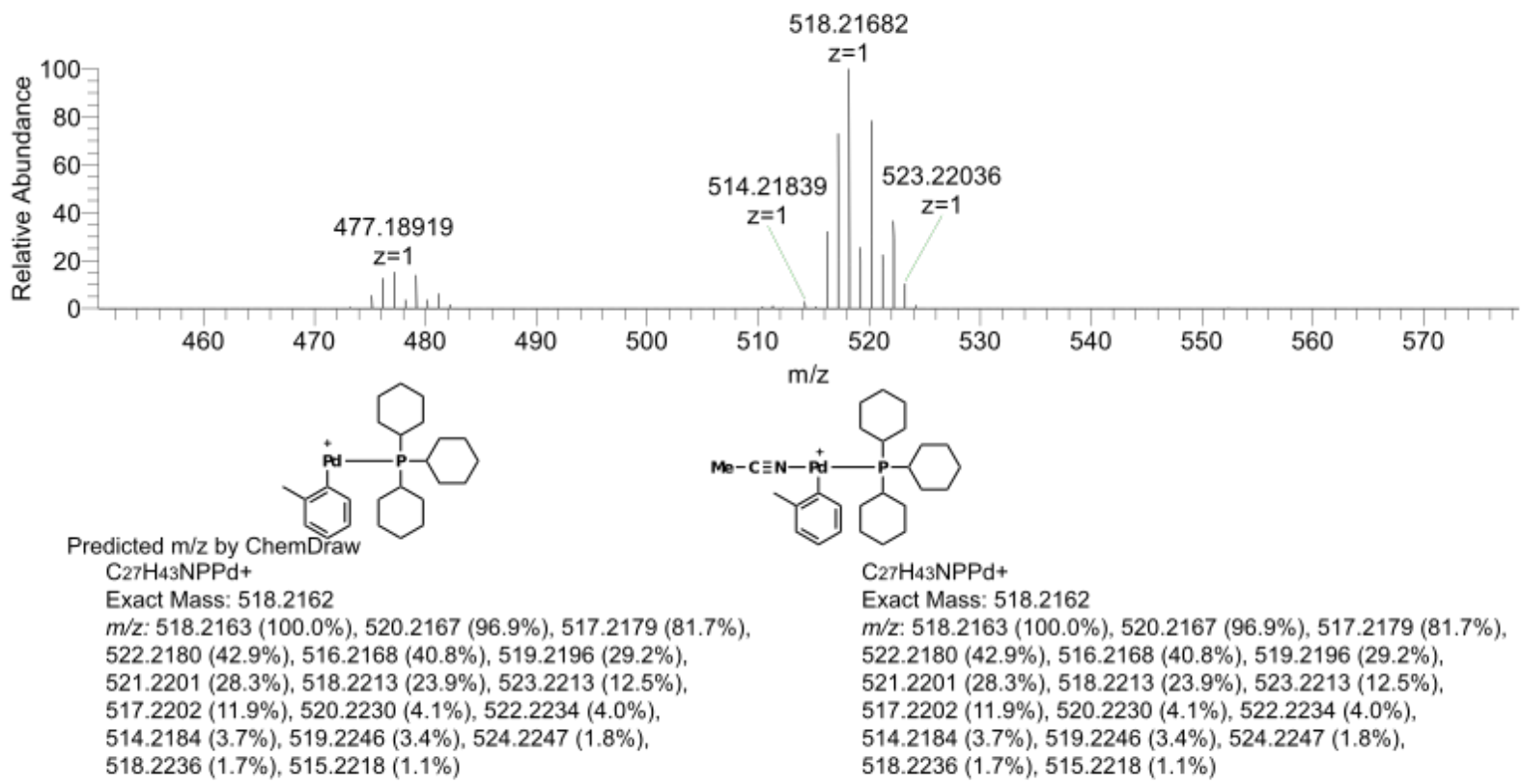


\section{Spectrum S5. LC-MS Spectrum of 1-C4 (ESI)}

C:XcaliburldatalKoidel85418LCMSPN

JKV2100-C4

RT: $0.00-30.02$ SM: $11 \mathrm{~B}$

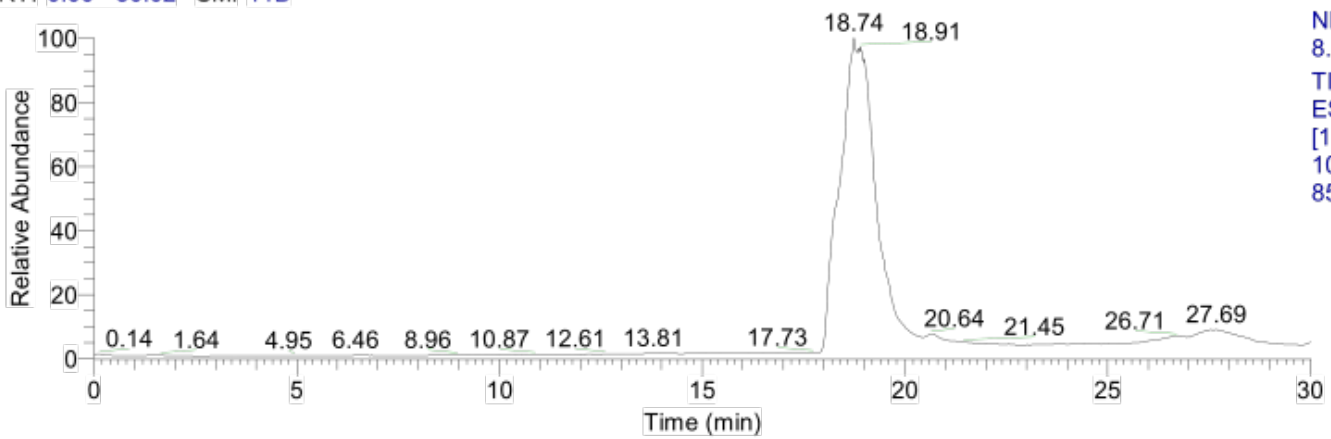

NL:

8.89E9

TIC F: FTMS + p

ESI Full $\mathrm{ms}$ [100.0000-

1000.0000] MS

85418LCMSPN

85418LCMSPN \#1649-1724 RT: 18.52-19.27 AV: 38 NL: 5.09E9

T: FTMS + p ESI Full ms [100.0000-1000.0000]

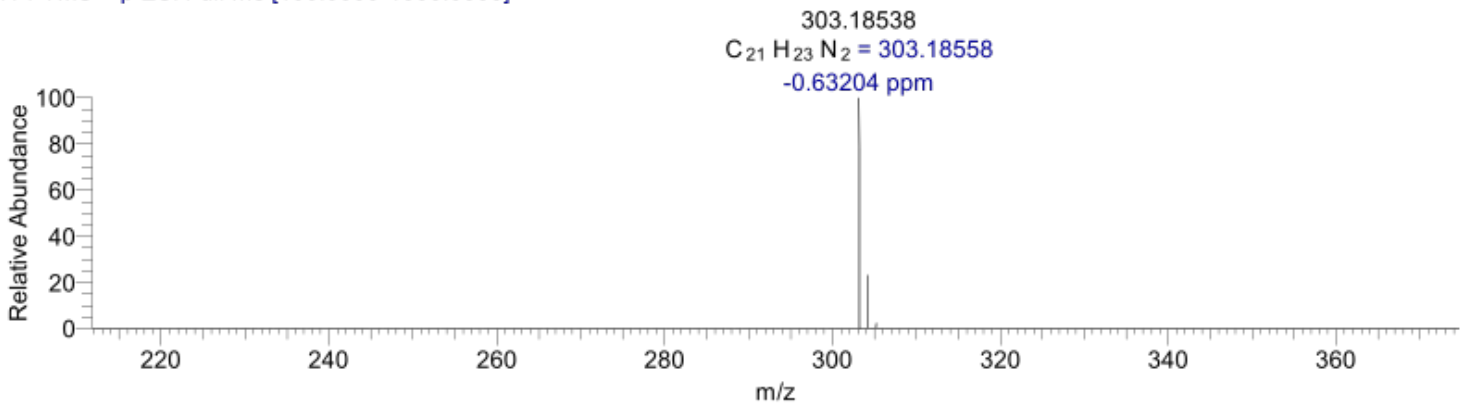

85418LCMSPN \#1817-1901 RT: 20.26-21.15 AV: 43 NL: 1.50E7

T: FTMS + p ESI Full ms [100.0000-1000.0000]

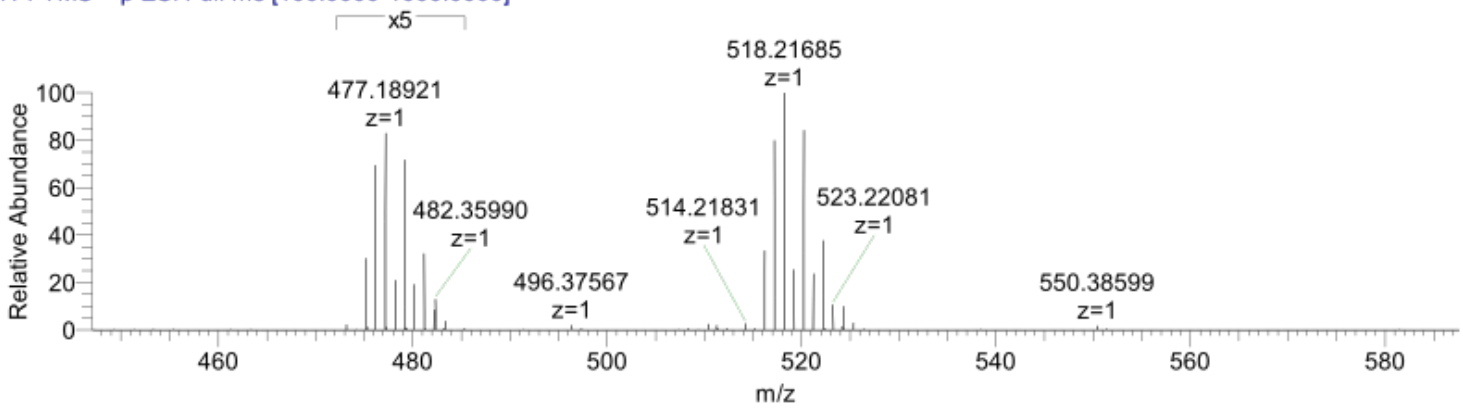

85418LCMSPN \#2441-2578 RT: 26.95-28.34 AV: 69 NL: 5.00E7

T: FTMS + p ESI Full ms [100.0000-1000.0000]

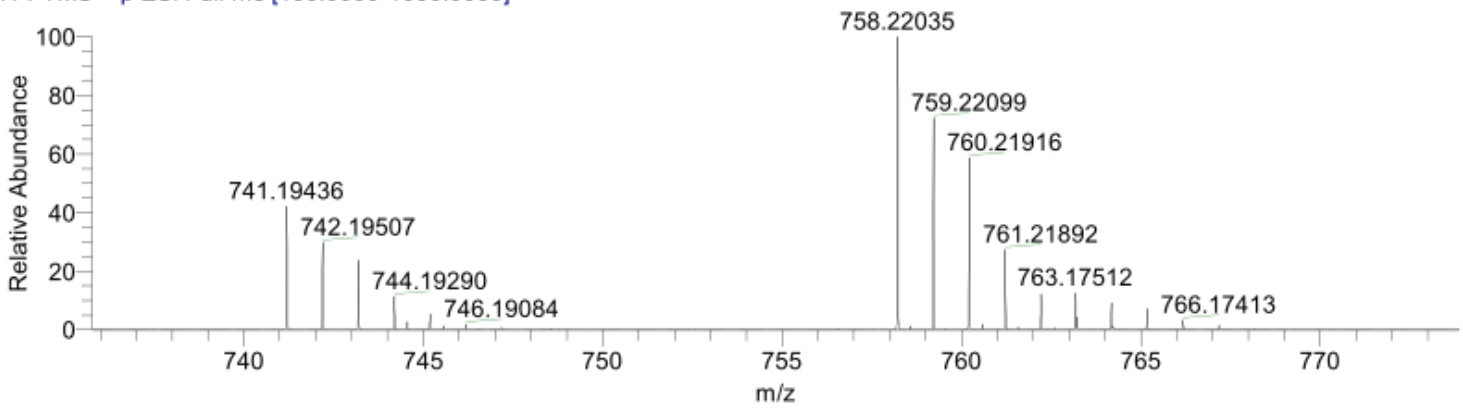


Spectrum S6. MALDI-TOF mass spectra of 1-C3 for Figure 3d.

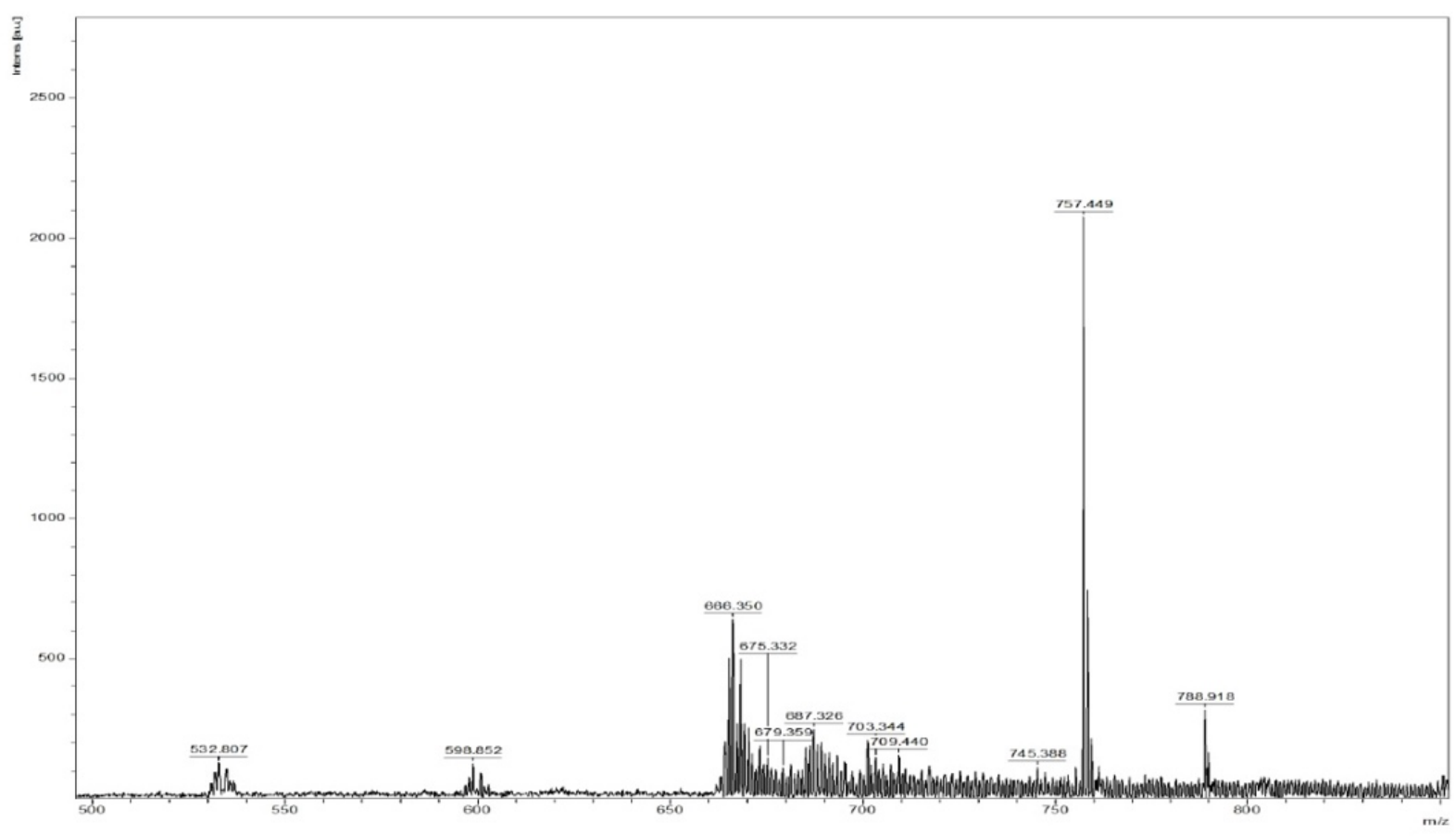

\begin{tabular}{|c|c|c|c|c|c|}
\hline $\mathrm{m} / \mathrm{z}$ & $\mathrm{S} / \mathrm{N}$ & $\begin{array}{r}\mathrm{Q} \\
\text { ua } \\
\text { lit } \\
\mathbf{y} \\
\mathrm{Fa} \\
\mathrm{c.}\end{array}$ & Res. & Intens. & Area \\
\hline 530.824 & 4 & & 2143 & 58.0 & 20.0 \\
\hline 531.823 & 7 & & 1087 & 96.0 & 54.7 \\
\hline 532.807 & 9 & & 1110 & 129 & 74.7 \\
\hline 534.833 & 8 & & 1164 & 108 & 64.9 \\
\hline 535.781 & 5 & & 992 & 63.4 & 45.1 \\
\hline 536.771 & 5 & & 1234 & 64.9 & 36.9 \\
\hline 597.845 & 5 & & 2756 & 77.0 & 24.4 \\
\hline 598.852 & 8 & & 2566 & 127 & 38.8 \\
\hline 600.849 & 6 & & 2299 & 92.9 & 27.8 \\
\hline 664.336 & 9 & & 2959 & 204 & 49.1 \\
\hline 665.349 & 23 & & 3046 & 502 & 103 \\
\hline 666.350 & 29 & & 2983 & 641 & 125 \\
\hline 667.345 & 12 & & 3043 & 269 & 58.8 \\
\hline 668.350 & 22 & & 2943 & 498 & 98.8 \\
\hline 669.343 & 12 & & 2960 & 268 & 60.9 \\
\hline 670.351 & 11 & & 3073 & 255 & 52.2 \\
\hline 671.342 & 7 & & 2636 & 162 & 49.1 \\
\hline 672.329 & 5 & & 2905 & 104 & 34.0 \\
\hline 673.331 & 8 & & 3128 & 190 & 45.3 \\
\hline 674.317 & 5 & & 2849 & 125 & 38.9 \\
\hline 675.332 & 6 & & 2710 & 147 & 43.4 \\
\hline 676.338 & 5 & & 2655 & 113 & 37.3 \\
\hline 677.387 & 5 & & 1787 & 106 & 42.4 \\
\hline 679.359 & 5 & & 1976 & 112 & 38.2 \\
\hline 681.400 & 5 & & 2349 & 123 & 42.0 \\
\hline 683.353 & 4 & & 2765 & 102 & 34.5 \\
\hline 684.332 & 4 & & 2630 & 103 & 31.0 \\
\hline 685.360 & 8 & & 2829 & 185 & 51.2 \\
\hline 686.339 & 8 & & 2916 & 191 & 50.1 \\
\hline 687.326 & 10 & & 3119 & 250 & 55.8 \\
\hline 688.322 & 8 & & 3130 & 196 & 45.9 \\
\hline 689.337 & 8 & & 3168 & 201 & 48.1 \\
\hline 690.338 & 7 & & 2757 & 160 & 45.1 \\
\hline 691.338 & 7 & & 2605 & 165 & 55.9 \\
\hline 692.356 & 5 & & 2883 & 129 & 37.1 \\
\hline 693.434 & 7 & & 2243 & 157 & 51.2 \\
\hline 694.462 & 4 & & 1836 & 101 & 38.7 \\
\hline 695.472 & 6 & & 2026 & 134 & 51.3 \\
\hline 697.385 & 4 & & 1922 & 99.1 & 40.2 \\
\hline 699.369 & 4 & & 2617 & 103 & 31.1 \\
\hline 701.371 & 9 & & 3017 & 212 & 51.9 \\
\hline 702.363 & 5 & & 3043 & 122 & 36.4 \\
\hline 703.344 & 6 & & 2760 & 149 & 44.3 \\
\hline 704.332 & 4 & & 3058 & 104 & 28.4 \\
\hline 705.353 & 5 & & 1740 & 126 & 49.8 \\
\hline 707.383 & 5 & & 2414 & 123 & 39.4 \\
\hline 709.440 & 6 & & 1975 & 156 & 53.3 \\
\hline 711.303 & 4 & & 1939 & 109 & 40.2 \\
\hline 717.367 & 5 & & 2607 & 117 & 37.4 \\
\hline
\end{tabular}


Table S1.

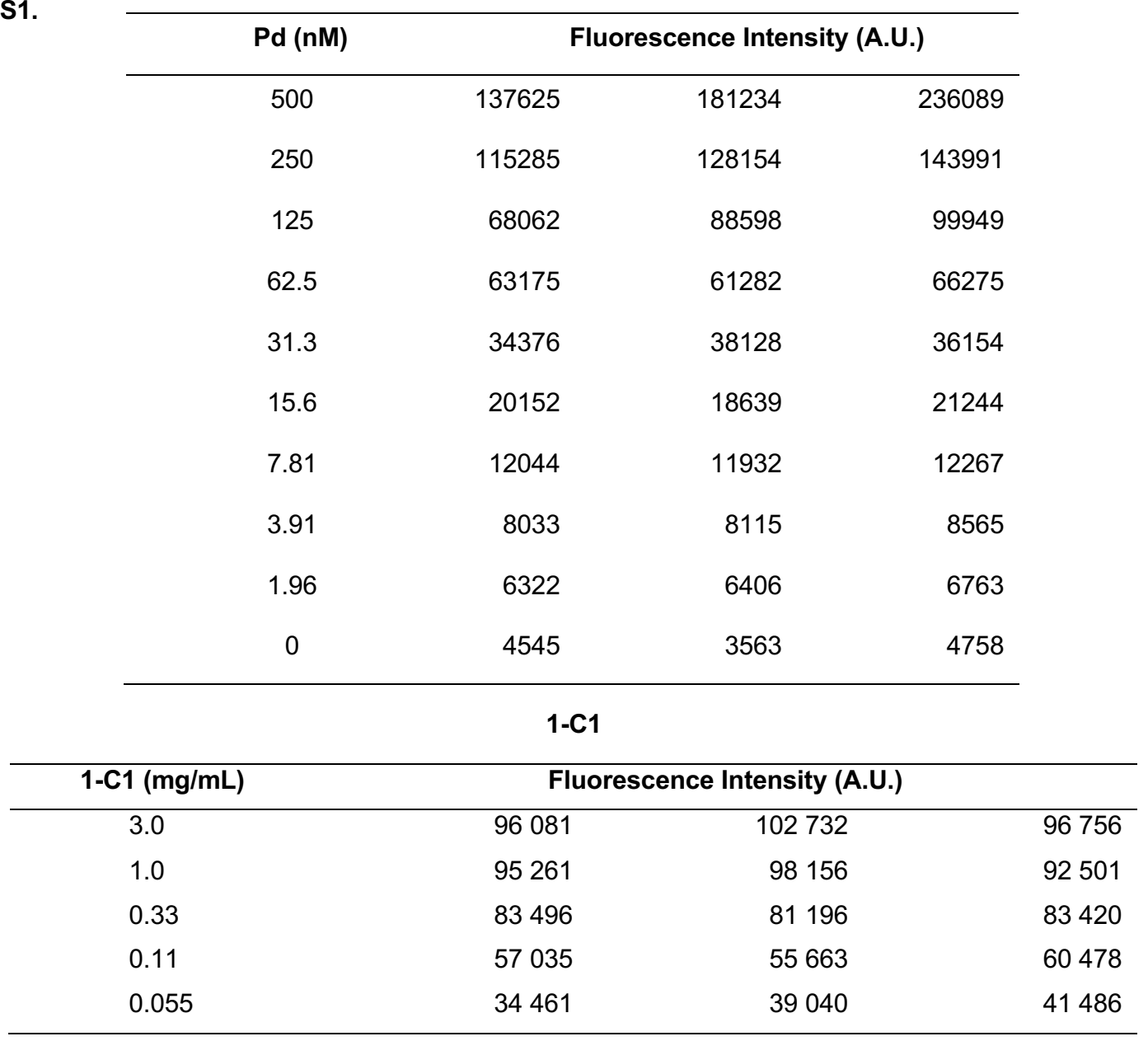

\begin{tabular}{cccr}
\multicolumn{1}{c}{ 1-C2 } & \\
\hline 1-C2 (mg/mL) & \multicolumn{1}{c}{ Fluorescence Intensity (A.U.) } \\
\hline 3.0 & 103797 & 114914 & 120581 \\
1.0 & 104030 & 94598 & 94251 \\
0.33 & 70403 & 71994 & 70787 \\
0.11 & 39130 & 45948 & 42803 \\
0.055 & 28556 & 36423 & 34881 \\
\hline
\end{tabular}

1-C3

\begin{tabular}{crrr}
\hline 1-C3 (mg/mL) & \multicolumn{2}{c}{ Fluorescence Intensity (A.U.) } \\
\hline 3.0 & 129039 & 123704 & 114286 \\
1.0 & 84430 & 83868 & 82080 \\
0.33 & 39794 & 39951 & 41639 \\
0.11 & 18767 & 18579 & 18224 \\
\hline
\end{tabular}




\begin{tabular}{cccc}
\hline 1-C4 (mg/mL) & \multicolumn{3}{c}{ Fluorescence Intensity (A.U.) } \\
\hline 3.0 & 84538 & 81162 & 79483 \\
1.0 & 38333 & 35491 & 35686 \\
0.33 & 15086 & 15371 & 16532 \\
0.11 & 8642 & 8172 & 8667 \\
\hline
\end{tabular}

\begin{tabular}{cccr}
\multicolumn{5}{c}{ 1-RC } \\
\hline 1-RC $(\mathbf{m g} / \mathbf{m L})$ & \multicolumn{4}{c}{ Fluorescence Intensity (A.U.) } \\
\hline 3.0 & 23601 & 29321 & 25747 \\
1.0 & 13427 & 11842 & 12285 \\
0.33 & 7063 & 6731 & 6581 \\
0.11 & 5243 & 4806 & 4627 \\
\hline
\end{tabular}

Standard Addition: $0.33 \mathrm{mg} / \mathrm{mL}$ 1-C3

\begin{tabular}{cccc}
\hline Pd Added (nM) & \multicolumn{3}{c}{ Fluorescence Intensity (A.U.) } \\
\hline 59.50 & 88558 & 78451 & 88436 \\
7.43 & 66422 & 64763 & \\
0 & 59745 & 69517 & 56952
\end{tabular}

\section{Cited References}

1 Koide, K. et al. A competitive and reversible deactivation approach to catalysis-based quantitative assays. Nat. Commun. 7, 10691 (2016).

2 Xu, L. et al. The amine-catalysed Suzuki-Miyaura-type coupling of aryl halides and arylboronic acids. Nat. Catal. 4, 71-78 (2021). 